Dr BOJAN DIMITRIJEVIĆ, naučni savetnik

Institut za savremenu istoriju

Beograd, Republika Srbija

UDK 323.26/.27(497.11)"2000"

bojands1@gmail.com

$355.35(497.1) " 2000 "$

originalan naučni rad / original scientific paper

primljeno / received: 25. 8. 2020.

prihvaćeno / accepted: 20. 11. 2020.

https://doi.org/10.29362/ist20veka.2021.1.dim.175-196

\title{
VOJSKA JUGOSLAVIJE U DOGAĐAJIMA 5. OKTOBRA 2000.
}

APSTRAKT: Članak daje pregled aktivnosti Vojske Jugoslavije u događajima oko saveznih izbora 24. septembra 2000, posebno u Crnoj Gori. Potom razmatra pripreme za eventualnu intervenciju i reakciju na širi narodni bunt koji je 5. oktobra 2000. doveo do smene režima Slobodana Miloševića, a zatim prihvatanja novog predsednika Vojislava Koštunice. Iako je izgledalo da će se i u ovoj krizi vojska poslužiti specijalnim, oklopnim i inžinjerijskim snagama radi intervencije (protiv sopstvenih građana), do toga nije došlo. Dokumenta govore da su pripreme vršene i da su samo masovnost opozicionog pokreta i sveopšte nezadovoljstvo stanjem u Srbiji uticali da ne dođe do oružane intervencije. Smirivanje političke situacije i ostanak istovetne komandne garniture na člu vojske doveo je do pada tenzija. Članak je zasnovan na originalnim dokumentima Vojske Jugoslavije koje je Generalštab Vojske Srbije i Crne Gore dostavio 2003. na traženje tadašnjeg ministra odbrane Borisa Tadića, kao i na zapisnicima sa kolegijuma načelnika Generalštaba Vojske Jugoslavije koji su oslobođeni tajnosti 2006. godine odlukom tadašnjeg načelnika Generalštaba general-potpukovnika Zdravka Ponoša.

KLJUČNE REČI: Srbija, Crna Gora, izbori, 5. oktobar 2000, Slobodan Milošević, Vojislav Koštunica, Nebojša Pavković, Vojska Jugoslavije, Generalštab

Jedno od pitanja sa kojim su se suočile nove demokratske vlasti u upravljanju Ministarstvom odbrane i Vojskom Srbije i Crne Gore (VSCG) bilo je ponašanje Vojske i vojnog vrha u danima oko saveznih izbora kao i petooktobarske smene vlasti 2000. godine. U tu svrhu ministar odbrane Boris Tadić, (na inicijativu autora ovog članka, tada u funkciji savetnika), tražio je od načelnika Generalštaba VSCG general-pukovnika Branka Krge zapisnike sa sednica Kolegijima načelnika Generalštaba Vojske Jugoslavije iz perioda septembaroktobar 2000, kao i svu relevantnu dokumentaciju komande 1. armije i Beogradskog korpusa o događajima od 1. do 5. oktobra 2000. godine. ${ }^{1}$ Nepuna dva

\footnotetext{
${ }^{1}$ Srbija i Crna Gora, Ministar odbrane, Ministar, br. 2292-2, 10. 9. 2003.
} 
meseca kasnije, Generalštab je dostavio delimično kompletnu dokumentaciju 1. armije i Beogradskog korpusa, iz koje može da se rekonstruiše aktivnost Vojske Jugoslavije (VJ) u tim prelomnim danima. ${ }^{2}$ Ukazujemo da bi za još detaljniji prikaz aktivnosti snaga VJ u tim danima jako interesantno bilo pronaći dnevne operativne izveštaje koje je sastavljao Operativni centar, kao detaljan pokazatelj svih aktivnosti vojske u toku jednog dana.

\section{Podrška Saveznoj izbornoj komisiji u Crnoj Gori}

Još pred održavanje saveznih izbora zakazanih za 24. septembar 2000, Izborna komisija Republike Crne Gore zamolila je Saveznu izbornu komisiju da od Generalštaba VJ zatraži odobrenje za korišćenje jednog broja poslovnih objekata u vlasništvu Vojske Jugoslavije, koji se nisu koristili za smeštaj i obuku vojske, za sprovođenje izbornih radnji na biračkom mestu u toj republici. To su uglavnom bili domovi vojske i još neke prostorije u Baru, Kotoru, Plavu, Tivtu, Pljevljima i Podgorici. ${ }^{3}$

Savezno ministarstvo za odbranu, na čelu sa generalom Dragoljubom Ojdanićem, ${ }^{4}$ dalo je pozitivno mišljenje i to istog dana kada je zahtev dostavljen 11. septembra 2000, ocenivši da je taj zahtev potrebno rešiti u što kraćem roku. ${ }^{5}$ Već sutradan načelnik Generalštaba VJ, general-pukovnik Nebojša Pavković, ${ }^{6}$ izdao je naređenje da njegov nadležni sektor preduzme mere kojima će izaći u susret crnogorskoj izbornoj komisiji i da se komande 2. armije i Ratne mornarice uključe u te pripreme. Odobreno je i da se traženi objekti mogu koristiti kao biračka mesta. ${ }^{7}$

Narednog dana, Savezna izborna komisija je tražila od načelnika Generalštaba ustupanje određenog broja motornih vozila za prevoz stranih posmatra-

\footnotetext{
${ }^{2}$ Srbija i Crna Gora, Generalštab Vojske Srbije i Crne Gore, Načelnik, str. pov. 3233-7, 5. 11. 2003.

${ }^{3}$ Savezna Republika Jugoslavije (SRJ), Savezna izborna komisija, br. 70/114-2, 11. 9. 2000.

${ }^{4}$ General Dragoljub Ojdanić je zamenio ministra Pavla Bulatovića koji je pod nerazjašnjenim okolnostima ubijen u restoranu FK Rad na Banjici, uveče 7. februara 2000.

${ }^{5}$ Savezno ministarstvo odbrane (SMO), Kabinet ministra, int. broj 1081-2, 11. 9. 2000.

${ }^{6}$ Nebojša Pavković (1946), general-pukovnik VJ. Sve vojne škole završio je u Beogradu: Vojnu akademiju Kopnene vojske (1970), Komandno-štabnu akademiju Kopnene vojske (1982) i Komandno-štabnu školu operatike (1988, prvi u rangu sa srednjom ocenom 10). Od 1989. radio je u kabinetu generala Veljka Kadijevića. Učesnik je, u činu pukovnika, u ratnim operacijama iz 1991. na vukovarskom ratištu. Od 1994. bio je, u činu general-majora, na dužnosti u Prištinskom korpusu Vojske Jugoslavije. Za komandanta korpusa postavljen je 9. januara 1998, a 21. jula iste godine unapređen je u čin general-potpukovnika. Ukazom Slobodana Miloševića od 25. decembra 1998. postavljen je za komandanta 3. armije VJ. Na tu dužnost stupio je 13. januara 1999, a u čin general-pukovnika unapređen je 31. marta 1999. Od februara 2000. do 24. juna 2002. bio je načelnik Generalštaba Vojske Jugoslavije. Pred Haškim tribunalom optužen je za zločine protiv čovečnosti (po četiri tačke: za deportaciju, prisilno preseljavanje, ubijanje i progon) i kršenje zakona i običaja ratovanja tokom sukoba na Kosovu i Metohiji 1999. godine. Tribunalu se predao 25. aprila 2005, suđenje je počelo 10. jula 2006, prvostepena presuda izrečena je 26. februara 2009, a pravosnažno je 23. januara 2014. osuđen na 22 godine zatvora. Kaznu izdržava u zatvoru u Finskoj.

7 SRJ, Generalštab Vojske Jugoslavije (GŠ VJ); Kabinet Načelnika Generalštaba (NGŠ), int. br. 2283-3, 12. 9. 2000; Isto, int. br. 2283-4, 13. 9. 2000.
} 
ča izbora na teritoriji Beograda. Saobraćajna uprava je, prema stavu generala Pavkovića, izabrala tri autobusa i pet putničkih automobila sa civilnim tablicama i vozačima, u kasarni ,Vasa Čarapić“‘. 8

Kako je bezbednosna situacija u Crnoj Gori počela da se komplikuje, Savezna izborna komisija se 22. septembra obratila generalu Pavkoviću i „zahtevala“ da pripadnici Vojske Jugoslavije „obezbede sva biračka mesta kao i rad izbornih komisija i svih biračkih odbora na teritoriji Crne Gore i dopremanje izbornog materijala u Saveznu izbornu komisiju“. Savezna izborna komisija je ukazala na ,pretnje i indicije da će tamošnje policijske snage pokušati da spreče održavanje izbora izazivanjem incidenata, nasilnim oduzimanjem izbornog materijala i drugim sredstvima“. 9

\section{Procene vojnog vrha o ishodu saveznih izbora 24. septembra 2000.}

Sudeći po sačuvanim zapisnicima sa kolegijuma načelnika Generalštaba $\mathrm{VJ},{ }^{10} \mathrm{u}$ vremenu pred savezne izbore (održana su dva kolegijuma: 22. i 23. septembra), problem koji je posebno istican bilo je stanje u Crnoj Gori i tamošnje političke reakcije, pre svega predsednika Crne Gore Mila Đukanovića. U tu svrhu načelnik Generalštaba VJ general Nebojša Pavković pozivan je kod predsednika SR Jugoslavije Slobodana Miloševića (identifikovali smo dolaske 22-23. i 27. septembra) na konsultacije. Pavković istih dana komunicira i sa načelnikom resora Državne bezbednosti Srbije (RDB) Radomirom - Radetom Markovićem. Na kolegijumu 22. septembra 2000, Pavković ističe Markovićevu procenu da u srpskoj opoziciji ,praktično... cene da će izgubiti izbore, da se prebace na prostor Crne Gore“, odnosno navodi ,prijatelja ovog mog šuraka, on je u opoziciji“ koji mu je rekao ,da oni imaju tačne ankete u kojim daleko vodi Miloševićc“.

$\mathrm{Na}$ istom kolegijumu, načelnik Obaveštajne uprave general Branko Krga ukazuje na „strani faktor“: „Znači prema našim analizama nije uopšte dilema da li će strani faktor da podstiče nered ili neće. To će sigurno da se dogodi. Samo je pitanje da li će ovi naši ovde, unutrašnji faktor, opozicija to prihvatiti i da li će moći da realizuje ono što od njih budu tražili“. Krga pominje nekoliko scenarija razvoja situacije, ocenivši da u tom trenutku postoje samo „dve opcije oko izbora, ili pobeđuje Koštunica ili su izbori pokradeni, mada interno svi cene da će pobediti Milošević“. Ukazao je da se ,sigurno... mora računati da će oni nešto da pokušaju“. Kao ciljeve eventualnih napada označio je „naravno rukovodstvo i to su objekti Vojske Jugoslavije.“ Moguće je, po njegovoj proceni, da ,dođe do sukoba ovde demonstranata u Beogradu

\footnotetext{
${ }^{8}$ SRJ, Savezna izborna komisija, br. 136-2000, 12. 9. 2000; SRJ, GŠ VJ; Kabinet NGŠ, int. br. 2283-6, 15. 9. 2000. i isto, 2283-7, 19. 9. 2000; GŠ VJ; Sektor za pozadinu, Saobraćajna uprava, int. br. 889-3, 18. 9. 2000.

${ }^{9}$ SRJ, Savezna izborna komisija, br. 259, 22. 9. 2000; SRJ, GŠ VJ; Kabinet NGŠ, int. br. 2283-8, 25. 9. 2000.

${ }^{10}$ Kolegijum NGŠ sačinjavali su osim načelnika i zamenika NGŠ načelnici sektora (8), samostalnih uprava (3), Inspekcije VJ i načelnik Kabineta NGŠ VJ. Po potrebi prisutni su bili pojedini načelnici uprava unutar sektora i portparol Vojske.
} 
ili u nekim drugim mestima“. Situaciju je „sa stanovišta spoljnog faktora“ ocenio kao „ozbiljnu“.

Načelnik uprave za moral i informisanje, general Milen Simić, izvestio je o aktivnostima u pogledu informisanja. Simić je bio zadužen i za brigu o izbornom materijalu i glasanje vojničkog sastava u jedinicama u Crnoj Gori. U toku je, po njegovim navodima, bio sledeći proces: „...direktno preuzimanje (izbornog materijala), nošenje u jedinice, glasanje i direktno vraćanje izbornim komisijama“.

General Pavković je izražavao zabrinutost u pogledu mogućnosti da posle završetka izbora MUP Crne Gore počne da presreće vozila sa izbornim materijalom i otima ga „bilo da ga falsifikuju, bilo da ga unište kao nepostojeći“. Iz tih razloga komandant 2. armije general Obradović trebalo je da „drži punktove na komunikacijama da pokriva svojim prisustvom punktove MUP-a Crne Gore... da preduzme mere da se zaštiti taj materijal... Jer oni ako kažu da nisu sproveli izbore i ako oduzmu materijal, ne možeš da dokažeš da su izbori bili. O tome se radi!“".

Uprava bezbednosti je procenjivala da je u Podgorici formiran štab u okviru tamošnjeg Centra bezbednosti i da su izrađeni „ratni planovi“ za postupke jedinica MUP-a Crne Gore, uključujući rušenje nekih objekata i komunikacija na pravcu ka Srbiji. Unutar Srbije praćena je aktivnost pripadnika pokreta Otpor (koji su bili u Vojsci), jer su podaci za njih dobijeni od Resora DB. Istaknuto je, međutim, „na osnovu dobre volje“, jer kod njih nije postojalo nikakvo naređenje o toj saradnji. Prema procenama načelnika te uprave generala Milana Đakovića u VJ je oko 45 lica pripadalo Otporu, još oko 40 lica je verbalno i na druge načine ,istupalo“, što čini 90-100 lica unutar VJ koji su se opoziciono deklarisali. Uprava bezbednosti je već od početka septembra imala zadejstvovane timove, od same uprave sve do brigada. Đaković je predložio da na dan izbora od 14 časova sve jedinice Vojne policije budu u prvom stepenu pripravnosti, jer su to ,jedinice koje bi morale biti prve upotrebljene“. ${ }^{11}$

Već sutradan, 23. septembra, održan je novi kolegijum. Uopšte uzev, stiče se utisak da je pred izbore vojni vrh bio u stalnom zasedanju. Oba kolegijuma, u odsustvu Pavkovića koji je bio na sastancima sa predsednikom Miloševićem, vodio je zamenik NGŠ general Svetozar Marjanović. Na početku ovog kolegijuma general Đaković upozorava na nedovršenost radnji oko kontrole pristizanja izbornih materijala iz izbornih jedinica, ukazujući da će u Crnoj Gori to biti najveći problem. Upućuje i apel: „sve na noge da danas ide da rade“. Zamenik NGŠ general Marjanović ističe da u pojedinim slučajevima „ne možemo ništa da uradimo“, dok Đaković insistira: „Možemo, možemo, ima da ide iz vojnog okruga organ bezbednosti i prisili ih da daju materijal koji treba da daju. Prisiliti, nije to nikakav problem. Mi ne tražimo ništa oko glasanja, nego da daju ono što su po zakonu dužni“. General Simić, pomoćnik načelnika Generalštaba za operativno-štabne poslove, upoznao je kolegijum sa dve naredbe

\footnotetext{
${ }^{11}$ SRJ, GŠ VJ, Kabinet NGŠ, Kolegijum načelnika Generalštaba Vojske Jugoslavije održan 22. 9.
} 2000, neautorizovan i nelektorisan magnetofonski snimak diskusija. VT-SP, Primerak br. 1. 
koje su upućene $\mathrm{u}$ jedinice $\mathrm{VJ}$ prethodne večeri: o podizanju borbene gotovosti $\mathrm{i}$ o izborima u Crnoj Gori.

Procenu Savezne izborne komisije od 22. septembra, u nešto oštrijem obliku, preneo je i Generalštab (Prva uprava, operativna) potčinjenim komandama 2. armije, Ratne mornarice i RV i PVO i naredio da se u Generalštabu formira 12člani tim na čelu sa zamenikom načelnika GŠ VJ i pomoćnicima NGŠ VJ radi praćenja toka izbora, ,uočavanja problema i preduzimanja odgovarajućih mera“. 12 U 2. armiji i Ratnoj mornarici sastav tima su činili načelnici štabova i pomoćnici komandanata. „Gotovost timova za rad 24. 09. 2000. godine u 07,00 časova“. Takođe naređeno je da komande 2. armije i Ratne mornarice upotrebe svoje jedinice vojne policije (4, 7. i 27. bataljon VP), tako što će izvršiti procenu glasačkih mesta i na ,pogodan način izvršiti obezbeđenje istih radi sprečavanja incidentnih situacija na izbornom mestu i krađe glasačkog materijala“" ${ }^{13}$

Admiral Zec je tog dana od načelnika GŠ VJ tražio prepotčinjavanje 6. čete 7. bataljona vojne policije specijalne namene, radi praćenja toka izbora, sprečavanja ometanja izlaska građana na glasačka mesta i onemogućavanja krađe glasačkog materijala. Četa je trebalo da bude angažovana od 18 časova 23. septembra do 8 časova 26. septembra, odnosno do otpremanja izbornog materijala na aerodrom Golubovci. ${ }^{14}$

General Simić navodi da je komandant 2. armije dobio zadatak da upozori predsednika Vlade Crne Gore i njenog ministra unutrašnjih poslova da će državno rukovodstvo i VJ ,po svaku cenu obezbediti normalne uslove za glasanje svih građana te republike“, da će ,u slučaju ekscesne situacije preduzeti energične mere prema nosiocima. Isključivu krivicu u slučaju incidentnih situacija snosiće vlada i MUP Crne Gore“.

U odgovoru na takvo angažovanje snaga VJ, pa i pismo generala Obradovića, komandanta 2. armije, od 23. septembra, predsednik crnogorske vlade Filip Vujanović istog dana ističe da smatra „krajnje nepotrebnim angažovanje vojne policije u osiguranju javnog reda i mira u danu izbora i to doživljavamo još jednom zloupotrebom VJ od strane savezne administracije“, tačnije Savezne izborne komisije. Uz isticanje da je bitno očuvati javni red i mir, podržao je predlog da se uspostavi zajednička saradnja MUP-a Crne Gore i Vojske Jugoslavije. Odbacio je, međutim, Obradovićevu konstataciju da su državni organi onemogućavali građane da izađu na izbore. General ga je, navodi Vujanović, obavestio „da će pripadnici VJ izaći na izbore“. To mu je ranije na sastanku istakao i admiral Zec, rekavši da će Vojska ,izvesti na izbore“ svoje pripadnike i članove njihovih porodica. Vujanović ističe da ne razume ,kako se individual-

${ }^{12}$ Sastav tima činili su: g.puk Svetozar Marjanović, rukovodilac, g.puk Miodrag Simić, zamenik i članovi: g.ppk Ljubiša Stojmirović, g.ppk Branislav Petrović, v.adm Vlade Nonković, g.maj Grujica Uskoković, g.ppk Branislav Obradović, gppk Zlatoje Terzić, g.ppk Branko Krga, g.ppl Milan Đaković i g.ppk Milen Simić.

${ }^{13}$ SRJ, GŠ VJ, Sektor za operativno-štabne poslove Prva uprava, str. pov. br. 04/7-49, 22. 9. 2000 (dobijena kopija nema drugu stranu).

${ }^{14}$ Komanda RM Kabinet komandanta, str. pov. br. 81-100/5, 23. 9. 2000. Četa je bila raspoređena u zoni odgovornosti Ratne mornarice i imala je vodove u Kumboru, Tivtu i Ulcinju. 
no građansko pravo može pretvarati u kolektivnu obavezu“. On naglašava da tu izjavu nije komentarisao, ,jer smatram da je to stvar odluke vojske za koju ste me Vi uvjeravali da nije politizovana“. ${ }^{15}$

Vraćamo se na kolegijum NGŠ gde je, kao četvrto, general Simić izvestio da su za potrebe prenosa glasačkog materijala iz Crne Gore do Savezne izborne komisije obezbeđena dva transportna aviona AN-26 i dva helikoptera Mi-8. Odnosno, da su na taj dan (23. septembar) obezbeđena dva transportna aviona AN-26 za prevoz starešina 2. armije i Ratne mornarice koji iz Crne Gore idu u Srbiju na glasanje.

Sledeće naređenje je bilo u vezi sa podizanjem borbene gotovosti jedinica VJ u Srbiji. Procena Generalštaba koju je potpisao general Pavković (da li je sa istom i predsednik Milošević bio upozoren?) od 22. septembra bila je: „Raspolažemo podacima da ekstremne opozicione partije pripremaju proglašenje pobede na izborima pre zvaničnog saopštavanja rezultata i već su javno zakazali proslavu ,pobede“ u večernjim časovima 24.9.2000. godine. Ovo ukazuje na već planirane scenarije izazivanja incidentnih situacija i nereda i neprihvatanja zvaničnih rezultata izbora." ${ }^{\text {"16 }}$ (Ovu procenu i naređenje koje sledi potom je na kolegijumu objavio i general Simić, pomoćnik načelnika GP za OŠP.)

Načelnik Generalštaba je, radi održavanja potrebnog nivoa borbene gotovosti i „sprečavanja svih mogućih oblika iznenađenja“, naredio da se u nivo gotovosti za upotrebu do 30 minuta prevedu jedinice vojne policije, izviđačke, izviđačko-diverzantske i čete-bataljoni za specijalna dejstva, kao i 72. specijalna, 63. padobranska i 46. zaštitna motorizovana brigada. Gotovost jedinica za upotrebu bila je u 18:00 časova 23. septembra 2000. Upotreba 63. padobranske brigade (tada pod komandom 3. armije) bila je sada moguća samo po odluci načelnika Generalštaba VJ.

Prema odlukama strategijskih grupacija (1-3. armija, RV i PVO, RM) trebalo je organizovati komandovanje formiranjem timova za komandovanje. Jedinice „A“ klasifikacije, koje su po naređenju o posebnim merama stalne borbene gotovosti bile $\mathrm{u}$ u gotovosti do 6 sati, trebalo je prevesti $\mathrm{u}$ jednočasovnu borbenu gotovost, zaključno sa 23 . septembrom do 18 časova. ${ }^{17}$ Simić je istakao da je prethodne noći načelnik GŠ naredio da ,jutros organizujemo i da sve jedinice koje su po ovom naređenju prevedene u jednočasovnu, odnosno polučasovnu borbenu gotovost na prostoru Beograda i bliže okoline proverimo ekipno“. ${ }^{18}$

Narednog dana, 23. septembra, zamenik NGŠ general-pukovnik Marjanović je naredio kontrolu borbene gotovosti u jedinicama 1. armije, RV i PVO i neposredno potčinjenim Generalštabu VJ, zaključno sa 17 časova. Kontrolisane su specijalne snage: Gardijska, 72. specijalna, 46. zaštitna brigada i bataljoni za

\footnotetext{
${ }^{15}$ SRJ, GŠ VJ, Kabinet NGŠ, int. br. 2283-12, pismo predsjednika Vlade Crne Gore Filipa Vujanovića, 25. 9. 2000.

${ }^{16}$ SRJ, GŠ VJ, Sektor za op. poslove, I uprava, s. pov. 04/7-48, 22. 9. 2000.

${ }^{17}$ Isto.

${ }^{18}$ SRJ, GŠ VJ, Kabinet NGŠ, Kolegijum načelnika Generalštaba Vojske Jugoslavije održan 23. 9. 2000, neautorizovan i nelektorisan magnetofonski snimak diskusija. VT-SP, Primerak br. 1.
} 
specijalna dejstva Beogradskog i Novosadskog korpusa, zatim oklopne jedinice, koje su bile značajne u pogledu eventualne upotrebe, pre svega 1. oklopna (Voždovac), a potom 453. oklopna brigada (Sremska Mitrovica) i oklopni bataljon 20. motorizovane brigade u Valjevu. Takođe, izvršena je kontrola ostalih jedinica: 305. inžinjerijske brigade - Šabac, 16. mešovite artiljerijske brigade Ruma, 12. i 401. artiljerijsko-raketne brigade PVO u Petrovaradinu i Jakovu, Rečne ratne flotile - Novi Sad, Graničnog dunavskog odreda, 14. i 15. graničnog bataljona u Banatu, kao i jedinica RV i PVO: 204. lap - Batajnica i 250. rbr PVO - Banjica). Kontrolni timovi su nosili lično naoružanje. ${ }^{19}$

U periodu pre izbora težišni angažman vojnog vrha bilo je praćenje izbora u Crnoj Gori i sprečavanje procenjene izborne pljačke. Događaji u Srbiji i u Beogradu bili su u manjem fokusu vojnog vrha i tek počinju da privlače pažnju od 23. septembra popodne. Ipak, za mirnodopske uslove sasvim je netipično angažovanje delova vojske u izbornim procedurama, kroz koordinaciju Sektora za operativno-štabne poslove, Uprave bezbednosti i Uprave za moral.

\section{Izbori 24. septembra: početak pada Slobodana Miloševića}

Da je Milošević dan odluke dočekao bez pripremljenog izlaza za slučaj nužde, jasno se videlo već samog 24. septembra. Izlaznost na izborima 24. septembra bila je velika. Već je to bio znak da će pobediti Demokratska opozicija Srbije (DOS) i njen kandidat. Iste večeri događaji su tekli bez većih problema. Ubeđen u svoju pobedu, Milošević nije naredio preuzimanje posebnih mera od strane njegovih predstavnika na izbornim mestima. Opozicioni predstavnici su bili u komisijama za brojanje glasova, prebrojavali su ih i svi su zajedno potpisivali zapisnike. „Bio sam u sedištu Demokratske stranke kad su mi sa deset različitih mesta iz Srbije stigli rezultati koji govore da Koštunica pobeđuje. Bio sam tada siguran u njegovu pobedu“, sećao se kasnije Zoran Đinđić, lider Demokratske stranke. Postalo je jasno da je opozicija pobedila na lokalnim i saveznim izborima. Pobeda liste od 18 stranaka Demokratske opozicije Srbije na čijem je čelu bio Vojislav Koštunica, lider Demokratske stranke Srbije, bila je očigledna.

Milošević je potom odbio da prizna pobedu opozicije, a njegovi saradnici su organizovali razvlačenje proglašenja izbornih rezultata. Već sutradan stotine hiljada razljućenih građana izašlo je na ulice širom Srbije. Usledilo je ubrzavanje političkih događaja. Budući da je Koštunica osvojio više glasova od Miloševića, socijalisti su odbili da priznaju te rezultate i objavili su drugi krug predsedničke trke. U tim trenucima bilo je vrlo teško osmisliti efikasan odgovor i odbraniti pobedu. Duge šetnje po modelu protesta u zimu 1996/97. nisu dolazile više u obzir, generalni štrajk takođe.

Zoran Đinđić je došao potom na ideju blokada, čiji je efekat zaustavljanje sistema. U Beogradu je rasla politička temperatura kroz večernja okupljanja. Takav sled događaja ponovo je ustalasao unutrašnjost Srbije. Započeli su prote-

${ }^{19}$ SRJ, GŠ VJ, Sektor za op. poslove, I uprava, s. pov. 04/7-51, 23. 9. 2000. 
sti, koji su se razvijali do neslućene masovnosti. Stvari su se sve više radikalizovale. DOS je procenio da ovu igru može da dobije samo ako ne popusti stisak oko Miloševićevog ,političkog vrata“. „Dosta je šetnji, pištaljki, mirnih protesta i davanja cveća onima koji nas biju“, poručio je 29. septembra Đinđić okupljenim Beograđanima. „Ne želimo da šetamo osamdeset osam dana, već da ovaj posao završimo za pet dana“. "Sve mora da stane da bi ponovo krenulo“. Sam Milošević nije odmah odlučno reagovao, jer je bio ubeđen da će njegova taktika razvlačenja uspeti i ovog puta.

$\mathrm{U}$ isto vreme, iako sastavljena od različitih i sitnih delova, opozicija je počela da hvata ritam protesta što se na delu uočavalo kao određena strategija. Konačno, svima je bilo dosta Miloševića, pa su se stvari po neki put kretale i same od sebe. Unutrašnjost Srbije je postala izuzetno agilna, sa raznih strana stizale su vesti o uspešnim blokadama. Ubrzo je i doneta odluka. Sva ta energija iz Srbije preneće se u Beograd, u četvrtak 5. oktobra, pre Miloševićevog drugog kruga izbora. Lideri DOS-a otišli su u varoši u unutrašnjosti da odatle stanu na čela kolona koje su čekale momenat da krenu za Beograd. Za to vreme Đinđić i Nebojša Čović su ostali u Beogradu da bi koordinisali akciju. Petog oktobra sav taj opozicioni talas zapljusnuće Beograd.

Najvažnija osobenost pristupa DOS-a (Đinđića) bila je da se ide do kraja i da se kao odgovor na policijsku silu primenjuju ista sredstva. Takav odlučan pristup davao je poleta svima koji su bili u organizaciji protesta i koji su stizali iz provincije u prestonicu. ${ }^{20}$

\section{Vojni vrh u danima između izbora i revolucije}

Procena VJ (Obaveštajne uprave, na kolegijumu 28. septembra) bila je da strani faktor svoje aktivnosti na političkom i vojnom planu prema SR Jugoslaviji usklađuje prema rezultatima izbora, ,s jasnim ciljem pružanjem demokratske podrške Demokratskoj opoziciji“. Očekivanje zvaničnih rezultata dovodilo je do ,brojnih špekulacija“" i ,uzdržanosti u ocenama zvaničnika“, pre svega Evropske unije, pri čemu Zapad ,podržava opoziciju“ u očekivanju drugog kruga izbora. „Mislimo da je sasvim jasno da u inostranstvu postoje neki centri moći koji žele da se kod nas dogodi krvavi scenario i ne samo da to žele već i da unapred isprovociraju“. Iako nije bilo ,indikatora neposrednog ugrožavanja SRJ“, načelnik Obaveštajne uprave general Krga je ukazao na moguć nepovoljan razvoj događaja. Situaciju je sveo na dve opcije: „prva da Demokratska opozicija prihvati prvi krug izbora i tu bi reagovanje vojske bilo pojednostavljeno i druga opcija je da se ne prihvate i kao što su sinoć najavili otpočnu sa masovnim protestima širom zemlje što bi ukomplikovalo situaciju“.

General Pavković je istakao da je situacija ,jasna“, jer je Savezna izborna komisija saopštila izborne rezultate. „Ni po kojoj osnovi opozicija nema razloga da bude nezadovoljna, dobili su u lokalu, stanje za predsednika Jugosla-

${ }^{20}$ Detaljnije u: Bojan Dimitrijević, Zoran Đinđić, Biografija (Beograd: Zavod za udžbenike, 2007), 121-125. 
vije potpuno jasno, jasni su rezultati“, ocenio je on. Najava protesta, međutim, bila je ozbiljan izazov. Pavković je stao na stanovište da treba proceniti buduće događaje i ono što očekuje vojsku u narednom periodu. „Mi sigurno se nećemo uključivati ni u kakve sukobe ako ne budemo napadnuti, ni mi, ni naše državne institucije“, istakao je Pavković i dodao da bi posle tog sastanka trebalo „da odemo do predsednika (Miloševića) da mi izložimo našu procenu, jer očigledno da neko nije uvažavao što smo mi slali tamo“.

Uprava bezbednosti je procenila da opozicija neće izaći „na izbore u drugom krugu“ i da se može očekivati „dalja destabilizacija stanja, i pritisak na vojsku i MUP“. Prema Đakovićevim podacima deo pripadnika VJ je glasao za DOS, ali to još uvek nije uticalo na borbenu gotovost. Ipak, nije se moglo proceniti kako će deo pripadnika, posebno starešina, reagovati u daljim događajima. Ponovo je istaknuto da je u Crnoj Gori izražen broj civilnih lica koji su naklonjeni rukovodstvu te republike.

U maniru moralista prethodnih epoha, general Milen Simić je ocenio: „Očito je da je i u predizbornoj kampanji, ali i sada izvedena klasična vojna psihološko-propagandna operacija pod jurisdikcijom Zapada sa glavnim ciljem da se otvore ratni ciljevi i to je suština... Nažalost na domaku su da postignu ratne ciljeve. Nažalost, jedino smo mi uočili to i jedino smo mi to nazivali pravim imenom i jedino smo mi delovali kroz naše angažovanje u cilju zaštite jedinice, svi ostali relevantni subjekti su se ponašali mirnodopski“،

Sam general Pavković je smatrao da je ,bez obzira na sve, vojska ostala kompaktna“, a da sigurno ima slučajeva pojedinačnog i ,raznoraznog nezadovoljstva“. On je u standardnom maniru te epohe istakao: „Mi mislimo da se ovo sve dešavalo po scenariju Zapada i da je to scenario kako treba da se razbije Jugoslavija, odnosno destabilizuje do kraja“. Dao je i sledeću ocenu: „Oni sada kroz ova okupljanja koja su počeli... to je svojevrstan pritisak na celokupno javno mnjenje u Jugoslaviji. To postaje prisutno svaki dan u narodu. Nema nikakvih kontra mera. To je sve stvar koju mi moramo da stavimo sa procenom i da vidimo“.

U tom trenutku - posle prvog kruga izbora i početka protesta u Srbiji Vojska drži i dalje deo jedinica u merama povišene borbene gotovosti „do 30 minuta“ i to 46. zaštitnu, 63. padobransku i 72. specijalnu brigadu, delove vojne policije i izviđačko-diverzantskih jedinica. Jedinice „A“ klasifikacije bile su u jednočasovnoj gotovosti. U skladu sa narastanjem protesta, Operativna uprava (general Ćurčin) predložila je snižavanje mera borbene gotovosti u jedinicama „A“ klasifikacije na 6 časova, a dodatno smanjenje mera u jedinicama vazduhoplovstva i mornarice. ,Vreme gotovosti stupanja na snagu ovih mera dakle za jedinice u šestočasovnoj gotovosti predlažemo da bude u 18,00 časova u subotu 30.09, po završetku zakletve vojnika i svečanosti proizvođenja studenata Vojne akademije, ukoliko ne bude pogoršanja situacije“".

Kolegijum održan tog dana general Pavković je zaključio rečima: „Ja mislim da smo mi sve ovo elaborirali. Sada je zadatak da se ovaj štab sastane u toku današnjeg dana, ali da se napravi kratka i jasna procena ovoga stanja sa predlozima mera šta treba uraditi. Ja ću da tražim da možda i večeras, a najverovatnije 
sutra, idemo kod predsednika ta jedna grupa koja bi iznela te stavove. Tu treba uključiti ovo što je iznosio Simić i ovo što je iznosio Krga i Đaković i naravno ovo što mi kroz ove naše razgovore ove stavove koje zastupamo u tom pogledu“ ${ }^{21}$

U tom periodu (2-3. oktobra), Vojska Jugoslavije je po odobrenju - naređenju načelnika GŠ VJ, kao i u prvom krugu izbora, dobila obavezu neposrednog preuzimanja, prevoza i vraćanja izbornog materijala. Ovlašćeni predstavnici vojnih odseka trebalo je da preuzmu od izbornih komisija sav propisno zapakovan i na vojne pošte adresiran materijal za birače koji glasaju u jedinicama VJ. Komande korpusa dobile su uputstvo o prenosu glasačkog materijala, pri čemu je posebno istaknuto: „Profesionalnim pripadnicima Vojske Jugoslavije, kao i za prvi krug glasanja, obezbediti da glasaju“، ${ }^{22}$

\section{2-4. oktobar: pripreme za intervenciju u Beogradu i Srbiji}

Već od 23. septembra Vojska je u suštini bila pripremana za akciju protiv opozicije u Srbiji. Tek će, međutim, opozicioni talas koji se podigao posle izbora 24. septembra i njegova ozbiljna pretnja uticati da u Vojsci započnu pripreme za moguću intervenciju.

$\mathrm{Na}$ osnovu usmenog naređenja komandanta 1. armije generala Trajkovića, Beogradski korpus, kojim komanduje general-major Božidar Delić (kasnije ugledni član Srpske radikalne stranke, potpredsednik Narodne skupštine i poslanik), formirao je 2. oktobra snage u nastavnom centru Bubanj Potok od delova 1. oklopne brigade (mehanizovani vod, samohodni haubički art. vod) i ojačanja (vod VP i samohodni vod PA oruđa $30 \mathrm{~mm}$ - „Prage“). Beogradski korpus je trebalo da formira grupe za raščišćavanje i u 453. oklopnoj i 305 . inžinjerijskoj brigadi (jačine po jedan tv, mv, tzi itd.).

U jedinicama korpusa naređeno je formiranje grupa ,za raščišćavanje puteva i barikada opremljene naoružanjem i sredstvima za brzo, efikasno, bezbedno uklanjanje barikada na komunikacijama i ulicama, koje sprečavaju normalno funkcionisanje jedinica, izdvojenih sastava i po potrebi građana“. Tako formirane snage trebalo je opremiti odgovarajućim sredstvima veze, „megafonom za komunikaciju sa demonstrantima, a vojnike, posade i posluge zaštitnim sredstvima, naoružanjem i manevarskom municijom za upozorenje, kao i bojevom municijom, napunjenom u okvirima - dobošima, za lično i zajedničko naoružanje spremno za upotrebu po komandi komandira grupe. Upotrebu grupa narediće Komandant beogradskog korpusa na predlog komandanta jedinice i procene situacije na terenu. Prilikom upotrebe grupe ne sme se dozvoliti prekoračenje ovlašćenja i prekomerna upotreba sile“", stoji u Delićevom naređenju. ${ }^{23}$

Komanda 1. armije je procenila da ,Situacija u zemlji postaje svakim danom složenija zbog neprihvatanja konačnih rezultata izbora od strane opozicionih

\footnotetext{
${ }^{21}$ SRJ, GŠ VJ, Kabinet NGŠ, Kolegijum načelnika Generalštaba Vojske Jugoslavije održan 28. 9. 2000, neautorizovan i nelektorisan magnetofonski snimak diskusija. VT-SP, Primerak br. 1.

${ }^{22} \mathrm{~K}$-da Beogradskog korpusa, s. pov. 16/nečitko-472, 3.10. 2000.

${ }^{23}$ Isto, 01/13-347, 2. 10. 2000.
} 
partija“. U skladu sa ovom procenom trebalo je izvršiti ,potpunu zaštitu značajnih objekata, ljudstva i dokumenata“ i ,stvoriti uslove da u svakom trenutku jedinice mogu izvršiti zadatke propisane Ustavom SRJ ne dozvoljavajući nikome da ih u tome ometaju“. Blokiranje objekata je trebalo onemogućiti, a u slučaju pokušaja blokiranja ulaza u objekte ,opomenuti aktere a po potrebi energično reagovati““ ${ }^{24}$

Prva armija je 4. oktobra 2000, kako je objašnjeno ,na osnovu ukazane potrebe za obezbeđenjem nesmetanog kretanja vojnih kolona u zoni odgovornosti VP 2082 (1. armije)“, naredila formiranje grupa za raščišćavanje sastavljenih od jednog mehanizovanog ili tenkovskog voda, putnog voda, odeljenja tenkova za izvlačenje i odeljenja vojne policije. Te grupe je trebalo rasporediti u očekujućim rejonima i u gotovosti da raščiste komunikacije i to kod:

- Novosadskog korpusa (dve grupe): kod 36. mehanizovane brigade (Subotica) za dejstvo pravcem Subotica - Novi Sad, i kombinovana grupa od Školskog centra OMJ (Pančevo), 51. mehanizovane (Pančevo) i 506. motorizovane brigade (Kikinda) pravcima Kikinda-Zrenjanin-Beograd i Pančevo-Alibunar-Vršac.

- Beogradskog korpusa (dve grupe): kod 453. mehanizovane brigade (Sremska Mitrovica) za pravac prema Šidu i pravac preko Rume ka Iriškom vencu, i kod 1. oklopne i VP 5062 Zemun sa lokacije Bubanj Potok prema Smederevu, odnosno Mladenovcu i Topoli. ${ }^{25}$

- Kragujevačkog korpusa (dve grupe): kod 252. oklopne brigade (Kraljevo), za pravac prema Raškoj i pravac Čačak - Gornji Milanovac.

- Drinske divizije (jedna grupa) kod 20. motorizovane brigade (Valjevo) za pravac prema Loznici i Rogačici.

- 305. inžinjerijske brigade u Šapcu (tri grupe u Sremskoj Mitrovici - poligonu Jevremovac, Šilopaj kod Gornjeg Milanovca i Devići kod Ivanjice) za dejstva iz Šapca prema Valjevu i Požegi, Bogatiću i Sremskoj Mitrovici i prema Obrenovcu i Lazarevcu, Gornjem Milanovcu i Čačku, Ljigu, odnosno Ivanjici, Arilju, Požegi, Čačku, Ušću i Kraljevu.

Bile su to lokacije sa očekujućih rejona i ,pravaca dejstva“, odnosno komunikacija odakle se očekivao dolazak protestanata u Beograd. ${ }^{26}$

Do 23 časa 4. oktobra, 1. oklopna brigada prihvatila je u svojoj kasarni na Voždovcu delove 72. specijalne brigade iz Pančeva. Brigada je dobila zadatak da za ovo ljudstvo do jutra 5. oktobra pripremi 10 borbenih vozila BVP sa posadama, bez ukrcnih delova. Ljudstvo 72. specijalne brigade je za naredni dan dobilo SDO (suvi dnevni obrok), siguran znak da se računa na njihovu vankasarnsku aktivnost. ${ }^{27}$

Četvrtog oktobra komanda Beogradskog korpusa naredila je da se počev od 14 časova u jedinicama korpusa u vanradno vreme nalazi 50\% pripadnika, a

\footnotetext{
${ }^{24}$ Isto, $01 / 13-349,2.10 .2000$.

${ }^{25}$ Ojačane oklopne snage 1. i 453. brigade za ovaj zadatak do 4. oktobra zauzele su položaje u Bubanj Potoku, kasarni „Vojvoda Stepa Stepanović“ na Voždovcu, u selu Stejanovci kod Laćarka i Ljuba kod Sremske Mitrovice. Ostale snage bile su u Nikincima i selu Klenje kod Bogatića. K-da Beogradskog korpusa, s. pov. 01/13-346, 2. 10. 2000; isto, 01/13-347, 2. 10. 2000; isto, 01/13-350, 4. 10. 2000.

${ }^{26}$ Komanda vp 2082, pov. br. 10/88-223, 4. 10. 2000.

${ }^{27}$ K-da Beogradskog korpusa, s. pov. 01/13-363, 5. 10. 2000.
} 
čak $100 \%$ u sastavu 55. bataljona vojne policije, 14. graničnog i 228. bataljona veze. Svi zahtevi za godišnje odmore ili odsustva su obustavljeni. Od raspoloživog ljudstva trebalo je formirati grupe za odbranu objekata. Ljudstvo, uključujući i civilna lica, trebalo je zadužiti formacijskom opremom i naoružanjem. ${ }^{28}$

Neobično je da istog dana Generalštab izdaje naredbu za formiranje dva pešadijska bataljona sa komandom u Obrenovcu. To su bili 58. i 59. pešadijski bataljon „NA“ (non-active) klasifikacije, pod komandom Inžinjerijskog školskog centra, a neposredno potčinjeni Generalštabu. ${ }^{29}$ Za sada nije jasno koje je ljudstvo trebalo da popuni ove jedinice i gde ih je trebalo upotrebiti.

\section{Peti oktobar - korak do intervencije}

Vojni vrh je u ranim prepodnevnim časovima pripremao snage za intervenciju. Načelnik GŠ general Pavković je 5. oktobra naredio 1. armiji: „Sprečiti prolaz učesnika rušilačkih demonstracija i ugrožavanje objekata u dodeljenom rejonu“" (podvučeno u originalu). Naređena je gotovost za posedanje i obezbeđenje rejona na prostoru Dedinja i Topčiderskog brda (sa tenkovskom četom i mehanizovanim vodom iz 1. oklopne brigade), delovi snaga iste brigade su bili spremni u kasarni ,Vojvoda Stepa Stepanović“ na Voždovcu za zatvaranje pravaca i raskrsnica Bulevar JNA - Crnotravska - Borska ulica, a rezerva sastavljena od čete VP i jedne motorizovane čete, pojačane sa pet oklopnih transportera iz 46. zaštitne mtbr, bila je u kasarni Topčider za angažovanje po posebnom naređenju. Inače, ova brigada imala je zadatak zaštite objekata Saveznog ministarstva odbrane i Generalštaba u ulici Kneza Miloša, u centru Beograda.

Kasarnu „Vasa Čarapić“ (na Banjici, pozadi VMA) obezbeđivale su snage 38. raketne artiljerijske brigade i 376. automobilskog bataljona koje su inače bazirale u njoj. Kasarnu ,Topčider“ obezbeđivali su 5. i 55. bataljon vojne policije i 398. puk veze. Sektori Generalštaba za elektronsko izviđanje i protivelektronska dejstva (EI i PED) i Školstvo, obrazovanje i naučno-istraživačku delatnost (ŠONID) imali su zadatak obezbeđenja objekata Vojne akademije, kasarne Sektora za ŠONID u Neznanog junaka 38 (zajedno sa delovima 46. zaštitne brigade) i Školskog centra veze na Banjici (u ulici Veljka Lukića Kurjaka). Snage RV i PVO obezbeđivale su njihovu kasarnu „Banjica“ u ulici Neznanog junaka do Ortopedske klinike.

Glavne specijalne snage bile su na sledećim lokacijama: Gardijska brigada u svojoj kasarni i na obezbeđenju vojnih i objekata od posebnog značaja; 72. specijalna brigada u kasarni „Vojvoda Stepa Stepanovićc u rezervi, u gotovosti da zatvori pravce koji izvode prema Dedinju; 63. padobranska brigada je bila u kasarni Vojne akademije, ali u gotovosti za angažovanje po posebnom naređenju. ${ }^{30}$

\footnotetext{
${ }^{28}$ Isto, s. pov. $01 / 13-363,4$. 10. 2000.

${ }^{29}$ Naredba III uprave GŠ, 3958-1, 4. 10. 2000. Jedinice rasformirane, odnosno: naređenje za njihovo formiranje ,stavljeno van snage“ 29. decembra 2000, III uprava GŠ, 4781-1, 29. 12. 2000.

${ }^{30}$ SRJ, GŠ VJ, Sektor za op. poslove, I uprava, s. pov. 04/7-69, 5. 10. 2000; Komanda 1. A s. pov. 3696-2, 5. 10. 2000, isto, 3696-10, 16. 10. 2000.
} 
Komanda Beogradskog korpusa procenila je tog jutra da se zbog „odbijanja izlaska na drugi krug izbora od strane opozicionih partija, situacija u zoni odgovornosti i dalje usložava“. Komandant korpusa general Delić je naredio: „Zabraniti uključivanje pripadnika Beogradskog korpusa i zloupotrebu sredstava ratne tehnike u aktivnostima opozicionih partija“. Oprez, ili čak strah od prelaska dela pripadnika korpusa na stranu opozicije (naroda) je vidljiv. Trebalo je sprečiti svaku mogućnost ,angažovanja ljudstva i sredstava ratne tehnike bez obzira gde se ona nalazi“", a posebnu pažnju obratiti u komandama i jedinicama gde je bio angažovan rezervni sastav. Uz angažovanje organa bezbednosti trebalo je pratiti mogućnost „eventualnog uključivanja pripadnika korpusa“ $u$,aktivnosti opozicionih partija“, pa i uz primenu ,svih raspoloživih zakonskih mera energično onemogućiti njihove namere“" 31

Obezbeđenje objekata i ljudstva bilo je planirano prema Pravilu službe VJ, ,a u slučaju neposrednog napada na ljudstvo i vojne objekte postupiti po pravilima borbene upotrebe“. Sasvim je sigurno, međutim, da kod profesionalnog sastava Vojske nije bilo raspoloženja da se preduzimaju bilo kakve agresivne mere prema narodu koji je želeo političke promene i čiji je broj rastao iz dana $\mathrm{u}$ dan. General Pavković u naređenju od 5. oktobra konstatuje kako „u poslednje vreme deo profesionalnih pripadnika VJ komentariše po izdatim naređenjima Načelnika Generalštaba VJ“; stoga upozorava da „naredbodavac nije dužan da objašnjava izdata naređenja“, da se u izvršavanju naređenja strogo pridržava tačaka 9 i 33 Pravila službe VJ, a da u slučaju neshvatanja naređenja profesionalni pripadnik može tražiti objašnjenje u skladu sa tačkom 35 Pravila službe VJ. ${ }^{32}$

\section{Uspeh opozicije i revolucije}

Narodni pokret 5. oktobra bio je jedinstven. Kolone koje su se kretale ka Beogradu bile su opremljene inžinjerijskim mašinama i uklanjale su postavljene barikade sa puteva. Đinđić je preko satelitskog telefona komunicirao sa kolonama i ljudima u gradu, što je u toku samih događaja osiguralo komunikacije od moguće provale od strane policije, ali preko koga je održavana veza sa relevantnim diplomatskim krugovima u Nemačkoj i SAD. Milošević se sada suočio sa dobrom organizacijom i realnim izazovom sopstvenoj vlasti. Pokazalo se da nije imao odgovor za takav izazov. Tog jutra Đinđić je svojim saborcima iz DOS-a jasno rekao da se ide do kraja.

Iako su tih dana do vrha DOS-a stizali mnogi glasovi sa druge strane da će se policija držati po strani, niko nije mogao da predvidi njeno držanje. Jedan od Đinđićevih postulata političkog delovanja bio je sledeći: u politici je radi efikasnosti ponekad potrebno „uprljati ruke“. Takav kompromis, ili svojevrsni pakt sa đavolom, bio je susret sa komandantom Jedinice za specijalne operacije (JSO) Resora DB Miloradom Ulemekom Legijom, uveče 4. oktobra, sa kojim je

\footnotetext{
${ }^{31}$ K-da Beogradskog korpusa, s. pov. 01/13-357, 5. 10. 2000.

32 SRJ, GŠ VJ, Sektor za op. poslove, I uprava, pov. br. 02/487-172, 5. 10. 2000; Isto, s. pov. 04/7-69, 5. 10. 2000; Komanda 1. A s. pov. 3696-2, 5. 10. 2000, isto, 3696-10, 16. 10. 2000.
} 
ugovorio njihovu neaktivnost u ključnim trenucima 5. oktobra. ${ }^{33}$ „Bez svih tih kompromisa mirni prevrat ne bi bio moguć, a mi možda ne bismo više bili u životu.“ Trebalo je imati nešto opipljivo. „I zbog toga je trebalo napraviti taj dogovor, dogovor sa đavolom ... ali taj dogovor je dao da su ljudi ostali živi“, smatra Zoran Živković, potpredsednik Demokratske stranke. ${ }^{34}$ Uprkos Legijinom upozorenju da će beretkama biti izdata komanda da intervenišu, Đinđić je jasno ponovio „da smo mi doneli odluku da idemo do kraja“. Njihov drugi susret bio je u kolima, usred gužve, kada je narod već bio ušao u Skupštinu.

A upravo je ta jedinica pružala sigurnost Miloševiću pred pretnjom od unutrašnjeg izazova, i samo mesec i po dana pre izvršila likvidaciju Ivana Stambolića, predsednika Predsedništva SR Srbije i Miloševićevog kuma, koji je u to vreme iskazao neke stavove o mogućem povratku u politiku, a protiv Miloševićevog režima. ${ }^{35}$

U do sada detaljno opisanim događajima na beogradskim ulicama oko Savezne skupštine mase su slomile otpor policije, ušle u praznu zgradu skupštine, posle kratkog oružanog otpora i u državnu televiziju, potom u policijsku stanicu u ulici Majke Jevrosime, a zatim i druge institucije. JSO nije intervenisala, mada se posle 16 časova pojavila na ulicama sa svojim oklopnim vozilima. Mnogo sveta nije ni znalo ko su ti ljudi, mislili su da je to vojska. Teatralno pokazivanje jedinice u gradu tokom popodneva 5. oktobra i još teatralniji „prelazak“ na suprotnu stranu bila je u stvari zaštita same JSO i Legijinih postojećih i budućih investicija u organizovani kriminal, od tada veoma mogućih radikalnih ishoda petooktobarskog prevrata. Može se reći da su DOS, Demokratska stranka i sam Đinđić naseli „na ovaj mangupski štos“ i da su svojim daljim postupcima abolirali ovaj Miloševićev eskadron smrti i otvorili mu prostor nekontrolisanog rada u naredne dve i po godine. Ipak, 5. oktobra nije bilo žrtava. Revolucija je uspela. ${ }^{36}$

Iako u pripravnosti i sa razvijenim snagama za intervenciju, Vojska Jugoslavije nije intervenisala ni na jednoj tački tog dana, osim što se možda nekoliko tenkova pokretalo u rejonu Bubanj Potok - Voždovac. General Pavković je, procenjujući masovnost demonstracija i njihov očigledan ishod, prečuo nekoliko Miloševićevih poziva. Vojne intervencije nije bilo. Ostalo je kontroverzno pitanje: da li je vrh Vojske Jugoslavije imao nameru da interveniše u toku masovnih demonstracija u Beogradu 5. oktobra? Model ranijih intervencija vojske upotrebom oklopne tehnike i specijalnih jedinica, kako izgleda, još uvek je bila zadnja karta za očuvanje vlasti Slobodana Miloševića. Pavković i vojni vrh, međutim, procenili su drugačije. Zadržali su svoje snage od izlaska na ulice i sukoba sa narodom. Tako su, kao i JSO Resora državne bezbednosti, sebi kupili ulaznicu za ,petooktobarsku“ Srbiju.

${ }_{33}$ Čedomir Jovanović, Moj sukob sa prošlošću (Beograd: Dan Graf, 2005), 31; Dragan Bujošević i Ivan Radovanović, 5. oktobar, Dvadeset četiri sata prevrata (Beograd: Medija centar, 2001), 47-50.

34 Jedinica III - film o Crvenim beretkama ili kako je ubijen Đinđić; treći deo, https://www.youtube.com/watchSDBVu3SKJQ.

${ }^{35}$ Isto.

${ }^{36}$ Isto, 43-212; B. Dimitrijević, n. d., 125-130. 


\section{7-12. oktobar: zadatak „Avala 2000““ - pripreme za intervenciju protiv snaga RDB Srbije}

Uspehom revolucije od 5. oktobra bezbednosno stanje se nije smirilo, mada je sad bilo van očiju šire javnosti. Vojne i jedinice RDB našle su se konfrontirane u narednim danima, a paralisanost većine institucija pogodovala je tom sukobu. Sačuvani dokumenti ovu situaciju nazivaju „Avala 2000 “. ${ }^{37}$

Tih nekoliko dana pripadnici Vojske i MUP-a (RDB) počeli su sa konfrontacijom oko sedišta Resora DB na Banjičkom visu - u kompleksu poznatom od ranije kao Institut bezbednosti. U tom kompleksu se nalazila JSO za koju u tom trenutku Generalštab ne zna da li priznaje lanac komandovanja MUP-a Srbije i Resora DB, ili je samostalna jedinica u službi DOS-a. Još gore, da li ima nameru da „krene na Generalštab“. Sve ovo dešava se na banjičkom polju, u radijusu od jednog kilometra.

Generala Pavkovića je ozbiljno brinula mogućnost da JSO napadne Generalštab. Sada su protivnici bili jasni. Pripadnici Vojske, od vrha do dna, uglavnom nisu podnosili pripadnike Resora DB zbog njihovih boljih plata, bolje opreme, naoružanja i vozila, uopšte privilegovanog statusa u Miloševićevoj epohi. S druge strane, i novoizabranom vrhovnom komandantu Koštunici trebalo je pokazati odlučnost.

Tokom nekoliko razgovora sa načelnikom Resora DB Markovićem Pavković je pokušao da ustanovi da li on ima komandu nad jedinicom ili ne. Iako je JSO u suštini mala jedinica, bojazan Generalštaba je bila velika. ${ }^{38}$ To pokazuju i preduzete mere. „Na osnovu ukazane potrebe a u cilju ojačavanja snaga za obezbeđenje vojnih objekata i objekata od posebnog značaja za odbranu SRJ“, naređeno je 10. oktobra 2000. da se izvrše pripreme „za dovođenje jedinica i posedanje očekujućih rejona“" ${ }^{39}$

Čitav sukob je, navodno, trebalo da bude rešen direktnim razgovorom u toku večere u Generalštabu između generala Pavkovića, načelnika Resora DB Markovića i komandanta JSO Ulemeka. Međutim, kada su pripadnici DB otišli, Pavković je po sopstvenom priznanju naredio da se „preduzmu neke mere“ i doveo pripadnike specijalnih jedinica u blizinu. Potom je naredio da se specijalnim snagama (72. brigada) opkoli sedište Resora DB na Banjičkom visu. One to i čine u 03:00 časa 7. oktobra. ${ }^{40}$

Štaviše, izdato je naređenje za pokret i grupisanje jedinica iz unutrašnjosti ka Beogradu. U tu svrhu naređeno je grupisanje jedinica 1. armije za intervenciju u kasarni Jakovo - privremena komanda 453. okbr bila je u kasarni Jakovo (sa tenkovskom i mehanizovanom četom, dve baterije VBR $128 \mathrm{~mm}$ iz 16. i 24. mabr i inžinjerijskom vodom 305. inžbr) odnosno 3. armije u kasarna-

\footnotetext{
${ }^{37}$ SRJ, GŠ VJ, Sektor za op. poslove I uprava, s. pov. 04/7-78, 9. 10. 2000.

${ }^{38}$ D. Bujošević i I. Radovanović, n. d., 257-259.

${ }^{39}$ SRJ, GŠ VJ, Sektor za op. poslove I uprava, s. pov. 01/2576-1, 10. 10. 2000.

${ }^{40}$ D. Bujošević i I. Radovanović, $n$. d., 259-260, 281.
} 
ma „Vojvoda Stepa Stepanović“ na Voždovcu i kasarni Bubanj Potok (komanda 3. odreda specijalne namene sa tenkovskom i mehanizovanom četom i samohodnom haubičkom baterijom/122. iz 211. okbr iz Niša, motorizovanom četom iz 125. brigade u Kruševcu i baterijom VBR iz 203. mabr u Aleksincu). Naređeno je dovođenje sopstvenim motornim vozilima iz Crne Gore jedne čete vojne policije iz 7. bataljona vojne policije specijalne namene u kasarnu „Banjica“, gde bi se ona prepotčinila 72. specijalnoj brigadi. Takođe, jedne pešadijske čete Pešadijskog školskog centra iz Požarevca i jedne tenkovske čete iz sastava Školskog centra OMJ, obe u kasarni „NH Stevica Jovanović“ u Pančevu. Tenkove i samohotke je trebalo prevesti železnicom, a ostale jedince došle bi marševanjem. Komandanti i komandiri ovih jedinica imali su da se jave komandantu 1. armije u Topčideru prepodne 10 . oktobra. ${ }^{41} \mathrm{U}$ dokumentima nismo identifikovali detalje dolaska niti razmeštanje snaga $\mathrm{VJ}$ za pojačanje.

Do smirivanja situacije konačno je došlo uz intervenciju političkih faktora kojima su se pripadnici MUP-a, RDB-a i Vojske prepotčinili. Sačuvano je naređenje od 12. oktobra po kome se vidi da su snage 63. padobranske brigade i jedne mehanizovane čete 3 . odreda specijalne namene vraćene u matične garnizone u Nišu i izašle iz privremene nadležnosti komandanta 1. armije. Povratak je naređen za 14. oktobar do 10 časova. ${ }^{42}$

\section{1. oktobar - dolazak novog predsednika SRJ Koštunice u Generalštab Vojske Jugoslavije}

Sama činjenica da je vojni vrh tokom 5. oktobra odbio da se uključi u događaje i interveniše na strani dotadašnjeg predsednika SRJ Miloševića, značila je da je otvoren put prihvatanju novoizabranog predsednika SRJ Koštunice.

Ubrzo, 11. oktobra, kada se postepeno stišavala tenzija sa snagama JSO RDB-a Srbije, predsednik Koštunica dolazi na kolegijum u Generalštab VJ. Pored Koštunice, koga prate šef njegovog kabineta Jeftić i načelnik vojnog kabineta general-pukovnik Šušić, prisutni su savezni ministar odbrane generalpukovnik Dragoljub Ojdanić, načelnik GŠ VJ general Pavković sa proširenim kolegijumom u kojem su komandanti sve tri armije, mornarice i vazduhoplovstva. Indirektno saznajemo iz referisanja tog dana, pa i obraćanja predsednika Koštunice, da se general Pavković sa njim susreće „skoro svakodnevno“, a da je to bio već drugi susret sa kolegijumom Generalštaba Vojske Jugoslavije. ${ }^{43}$

Pavković je bio medijator sastanka između „starog" i ,novog“" predsednika SRJ Miloševića i Koštunice 6. oktobra uveče i jedini svedok tog sastanka u Miloševićevoj rezidenciji, do koje je vozilima iz Palate federacije dovezao Vojislava Koštunicu. Nešto kasnije Milošević se obraća preko jednog TV kanala i priznaje pobedu novog predsednika. Sutradan Koštunica polaže svečanu zakle-

\footnotetext{
${ }^{41}$ SRJ, GŠ VJ, Sektor za op. poslove I uprava, s. pov. 01/2576-1, 10. 10. 2000.

${ }^{42}$ Komanda 3. A, s. pov. 170-279, 12. 10. 2000.

${ }^{43}$ SRJ, GŠ VJ, Kabinet NGŠ, Kolegijum načelnika Generalštaba Vojske Jugoslavije održan 11. 10. 2000. neautorizovan i nelektorisan magnetofonski snimak diskusija. VT-SP, Primerak br. 1.
} 
tvu. ${ }^{44}$ Novi predsednik je i formalno imenovan. U tom trenutku, on pod svojim realnom komandom ima samo Vojsku Jugoslavije.

General Pavković je u ime svih pripadnika Vojske i svog kolegijuma poželeo dobrodošlicu novom predsedniku uz reči ,danas želimo da vas upoznamo sa stanjem borbene gotovosti Vojske Jugoslavije, kao i sa problemima sa kojima se suočavamo i merama koje smo preduzeli odnosno koje sada preduzimamo" ${ }^{45}$ Usledila su referisanja Pavkovićevih pomoćnika i komandanata strategijskih grupacija.

Retorika je tom prilikom bila upadljivo drugačija od one korišćene samo pre nekoliko dana - pre 5. oktobra. General Krga, koji prvi referiše, sada ovako ocenjuje političku situaciju: „Stav stranoga faktora prema izbornom procesu u SRJ je bio u centru našeg interesovanja proteklih dana, kao što smo zapazili pozdravljeni su rezultati izbora i smena vlasti. Ponašanje Vojske Jugoslavije je veoma visoko ispoljeno. Najavljeno je uključivanje Jugoslavije u procese kao što su Pakt za stabilnost jugoistočne Evrope a u nekim kontaktima se pominje i Partnerstvo za mir“، ${ }^{46}$

Pomoćnik za operativno-štabne poslove general Miodrag Simić, koji je operativno vodio sve pripreme oko angažmana Vojske u prethodnim događajima, sada daje sledeću ocenu situacije: „Razvoj događaja neposredno pre održavanja izbora i posebno posle njih je usložio dodatne postojeće probleme VJ. I pored toga komandovanje je obezbedilo da VJ deluje u skladu sa ustavnim i zakonskim ovlašćenjem uz preuzimanje adekvatnih mera borbene gotovosti, radi sprečavanja svih mogućih oblika iznenađenja kojima se ugrožava bezbednost SRJ. Na taj način dat je pun doprinos za mirno i institucionalno rešavanje krize“ 47

Načelnik uprave za informisanje i moral Milen Simić, koji je bio zadužen za organizovanje praćenja izbornih radnji i materijala, ističe: „Imajući u vidu dostignuti nivo borbene gotovosti komandi jedinica i ustanova VJ, iskazanu zrelost, ustavni i profesionalni odnos pripadnika vojske povodom predsedničkih i parlamentarnih izbora u našoj zemlji cenimo da je sačuvano jedinstvo armijskog sastava. Uprkos delovanju brojnih negativnih činilaca u nastaloj situaciji očuvano je dobro i stabilno stanje morala vojske, koje omogućava uspešno izvršavanje njenih ustavnih zadataka. Takvom stanju morala doprinele su realna i pravovremena procena vojnopolitičke i bezbednosne situacije u okruženju i u zemlji“، 48

Načelnik Uprave bezbednosti general Đaković nema više onako oštre tonove o delovanju organa bezbednosti na glasačkim mestima. Sada on prilično suvo konstatuje: „U izbornom i post-izbornom periodu ponašanje pripadnika vojske bilo je u skladu sa Zakonom o VJ i njenom ustavnom pozicijom. Smatramo i predlažemo da se moraju preduzeti mere da svi politički faktori striktno ispoštuju vanstranačku poziciju VJ“. Ukazuje, međutim, na probleme u odnosima

\footnotetext{
${ }^{44}$ D. Bujošević i I. Radovanović, $n$. d., 263-265, 269.

${ }^{45}$ SRJ, GŠ VJ, Kabinet NGŠ, Kolegijum načelnika Generalštaba Vojske Jugoslavije održan 11. 10. 2000, neautorizovan i nelektorisan magnetofonski snimak diskusija. VT-SP, Primerak br. 1. 
sa snagama MUP-a (Srbije). „Stanje u zemlji u postizbornom periodu opterećeno je brojnim negativnim pojavama koje narušavaju sistem bezbednosti, ugrožavaju javni red i mir i prete da izmaknu kontroli državnih organa i institucija. Ispoljeno nejedinstvo u izvršavanju zadataka uslovilo je da se konsolidacija organa jedinica MUP-a odvija sporo. Situaciju dodatno usložavaju nastojanja pojedinih političkih faktora da na neke organe jedinice MUP-a izvrše uticaj i pridobiju ih za ostvarivanje svojih ciljeva. Opšte konfuzno stanje smišljeno koriste razne parapolicijske snage i kriminalne naoružane grupe i pojedinci koji pod vidom nove vlasti i demokratskih procesa nastoje da preuzmu funkcije pojedinih državnih organa“ ${ }^{49}$

General Đaković kritikuje i praksu nastanka „,kriznih štabova“ u pojedinim institucijama: „Cenimo da dodatnu opasnost za mir u zemlji predstavljaju postupci i ponašanje kriznih štabova na preuzimanju privrednih, informativnih, finansijskih i drugih republičkih i saveznih institucija. Do sada je nasilnim putem izvršena smena direktora ili rukovodstava u 65 radnih organizacija, institucija, a vrše se pripreme i traži smena u još 20-tak preduzeća među kojima je jedan broj od posebnog značaja za odbranu zemlje“. Slično su govorili general Vladimir Lazarević u preseku stanja na teritoriji 3. armije, odnosno general Spasoje Smiljanić u vezi sa stanjem u Saveznoj upravi kontrole letenja. ${ }^{50}$

Referisanje komandanta 2. armije generala Obradovića o stanju u Crnoj Gori bilo je u duhu isticanja poremećenih odnosa na teritoriji te republike, od odnosa vlasti prema vojsci do podela po raznim osnovama. Obradović se založio za ,brže“" rešavanje ove problematike u narednom periodu. ${ }^{51}$

U svom obraćanju general Pavković je istakao ono što je u tom trenutku tištalo vojni vrh. Nastojali su da nikako ne dođe do smena (,,kadrovskih promena"), a sve po saznanjima generala koji sad nisu bili u političkoj garnituri na vlasti, kao Perišić ili Grahovac. Njihov uticaj na Koštunicu trebalo je sprečiti i sačuvati se od eventualne njihove osvete, odnosno od bilo kakvih personalnih promena. Pavković detaljno obrazlaže svoj stav i eventualne kadrovske promene, i već u tom trenutku to karakteriše kao napad i na samog predsednika Koštunicu:

„Gospodine predsedniče, Vojska Jugoslavije je praktično ostala nedodirljiva za sve pokušaje naročito nekih naših ranijih kolega, pa i drugih uticaja da unesu da uđu u organizaciju vojske da pokušaju da iz te organizacije praktično deluju na njeno rasturanje i dezintegraciju. Mi odbacujemo sve tvrdnje pa i te od generala Perišića i ostalih koji evo danas vidim u štampi tvrde da je zahvaljujući njima vojska ostala u kasarnama, itd. Ovde stoje najodgovorniji ljudi koji znaju kakvi su to pokušaji nekorektni bili i šta se tu zapravo događalo.

Ja sam Vam na jučerašnjem jednom razgovoru kratko referisao i izneo sam mišljenje ovoga kolegijuma ovde da jednostavno smatramo da treba u najužoj konsultaciji sa ljudima koji ovde sede saslušati predloge u vezi sa kadrovskim rešenjima u Vojsci Jugoslavije jer ćemo mi koji znamo kakvo je to stanje i poznajemo već sebe sigurno predložiti one ljude koji mogu da dalje rade i na

\footnotetext{
49 Isto, 11.

50 Isto, 16-18.

${ }^{51}$ Isto, 15-16.
} 
očuvanju i jedinstva i izgradnji borbene gotovosti vojske. Naravno smatramo svi ovde da ne bi bilo dobro donositi ishitrena rešenja i pod uticajem raznih stranačkih lidera, ali i nekih ljudi koji jednostavno ne poznaju stanje u vojsci. Barem ne dok se ne izvrši konstituisanje saveznih institucija, skupštine i vlade pa i republičkih koji su na pomolu i dok se ne obezbedi stabilizacija stanja $u$ našoj zemlji a zatim naravno ja sam prvi spreman, a verovatno i moje kolege da se ponašamo onako kako Vi budete dozvolili.

Upozorio bih da ima sigurno pokušaja da se preko destabilizacije u vojsci verovatno utiče i na položaj institucije predsednika SRJ koji je praktično tek sad i počeo da radi. Mi naravno ne možemo prihvatiti takve uticaje i u tom pogledu bismo savetovali da imate puno poverenja u Vojsku Jugoslavije i da neće biti nikakvih iznenađenja niti izlaska iz okvira njenih ustavnih ovlašćenja“ ${ }^{52}$

Na kraju sastanka, novi predsednik SR Jugoslavije Koštunica je u dužem obraćanju istakao da ima ,puno poverenje u VJ i njen starešinski kadar. Mislim da u tom pogledu stvari budu jasne“. Kritikujući više puta ,američki hegemonizam“ ili „NATO-ovsku agresiju“, Koštunica je iznosio stavove sa kojima se najveći deo vojnog vrha u potpunosti još od ranije identifikovao. Skicirajući međunarodni položaj zemlje i promene posle smene vlasti najavio je sastanak Vrhovnog saveta odbrane, ali je istakao da je u mnogim post-5. oktobarskim događajima bio, kako je sam rekao, „neobavešten“.

Glavni cilj - sprečiti smene u vojnom vrhu - Pavković je odlično ostvario. Novi i u kadrovsku problematiku vojnog vrha slabo upućen predsednik SRJ, prihvatio je Pavkovićeve sugestije o potrebi nemešanja ljudi iz politike u personalne promene. Tako Koštunica u završnom delu svog obraćanja ističe:

„I najzad da kažem, ukoliko nastojim i nastojaću da se krećem u okviru nečega što je legalna procedura i da suzbijam nešto što je nestabilnost u ovom društvu svim raspoloživim sredstvima, onda budite uvereni da ću se isto tako odnositi prema VJ. Prema tome, bilo kakvo unošenje nestabilnosti u VJ i bilo kakvi razgovori ili planovi o kadrovskim promenama u VJ je nešto o čemu u ovom trenutku apsolutno ne treba razmišljati i tu delim stav koji je ovde iznet i koji je izneo general Pavković, mi moramo u ovom trenutku sačuvati jednu instituciju koja je od značaja za bezbednost naše države i naroda, a posebno je važno u jednom trenutku kada tek dolazi do procesa konstituisanja nove vlasti, to je Vojska Jugoslavije“" 53

Ovo je bila „muzika za uši“ većine generala u Pavkovićevom kolegijumu. Koštuničine reči nagovestile su da će sve kadrovske promene u Vojsci nadalje rešavati Pavković, sada oslobođen ranije bojazni od autoriteta Slobodana Miloševića. Štaviše, na ovaj način je sprečeno eventualno postavljanje generala Momčila Perišića, ranijeg načelnika GŠ VJ a sada jednog od lidera DOS-a, za saveznog ministra odbrane. Takođe, i 1999. godine penzionisanog generala Blagoja Grahovca, koga je sada podržavao crnogorski politički vrh, za neku od dužnosti u sistemu odbrane. ${ }^{54}$

\footnotetext{
52 Isto, 19.

53 Isto, 23.

${ }^{54} \mathrm{O}$ ovom Koštuničinom stavu general Pavković je izvestio već naredne nedelje, na kolegijumu održanom
} 
Tako je novi predsednik upoznat sa stanjem u Vojsci. Opšti utisak, i pored silnih teškoća, bio je da Vojska izvršava svoje zadatke maksimalno i profesionalno. General Pavković završava prvi deo referisanja ukazujući novom predsedniku da je vojska pod njegovom direktnom komandom: „Znači to je ta palica kojom Vi komandujete, dirigujete u odnosu na sve ostale savezne institucije“. Pavković ističe da je Vojska, u suštini: vojni vrh - Generalštab ostao ,jedinstven, pokazao visok profesionalizam i visok patriotizam"“. 55

Svoj kalkulantski prolazak kroz smenu vlasti izvršenu 5. oktobra Pavković objašnjava na sledeći način: ,...i mislim da smo odoleli svim pritiscima, svim pokušajima da se u Vojsku Jugoslavije unese i nejedinstvo i razdor. I događanja u toku ove godine $\mathrm{i}$ u predizbornom periodu, pa i danas pokazala su da smo krajnje profesionalno procenjivali situaciju i donosili odluke“" ${ }^{56}$

Nigde ni traga o uključivanju u izborne radnje, boravku specijalnih jedinica u prestoničkim kasarnama, pomeranju tenkova $i$ inžinjerijskih mašina, radu na sprečavanju narodne izborne volje. Raniji Miloševićevi jastrebovi u Generalštabu sada se pretvaraju u dosledne zagovornike demokratije i striktne vanpolitičke uloge vojske. Sve u duhu ,profesionalizma“ - i po ukusu novog predsednika.

\section{4. oktobar: Milošević više nije poželjan u Vojsci}

Ubrzo dolazi i potvrda da je Koštunica u potpunosti prihvaćen od vojnog vrha: raniji vrhovni komandant predsednik SRJ Slobodan Milošević nije bio više poželjan. Ni kao gost. Dana 14. oktobra, u podne, zaseda kolegijum načelnika Generalštaba. ${ }^{57}$ Druga tačka dnevnog reda je suštinska: „Zahtev prethodnog predsednika SRJ Slobodana Miloševića da se obrati kolegijumu i iznese svoje procene“. General Pavković izveštava saradnike da mu je prethodnog dana preko predsednika Republike Srbije Milana Milutinovića stigao Miloševićev zahtev da se lično obrati Kolegijumu NGŠ VJ i,,iznese svoje procene trenutne situacije“. Pavković je odmah o tome obavestio načelnika Uprave bezbednosti general-potpukovnika Đakovića i zahtevao sastanak sa novim predsednikom SRJ Koštunicom.

Već na početku svog obraćanja Pavković navodi da nije saglasan sa zahtevom bivšeg predsednika Miloševića i naglašava: „Da smo tokom izbora i posle izbornih događaja kao VJ i kao GŠ VJ očuvali jedinstvo, održali zahtevani

17. oktobra 2000. Tom prilikom general Marjanović, Pavkovićev zamenik, ističe: „Moramo da ostanemo pri tome što smo zaključili: svako dovođenje lica koja su penzionisana zbog toga, znači razbijanje vojske“. SRJ, GŠ VJ, Kabinet NGŠ, Kolegijum načelnika Generalštaba Vojske Jugoslavije održan 17. 10. 2000, neautorizovan i nelektorisan magnetofonski snimak diskusija. VT-SP, Primerak br. 1.

${ }^{55}$ SRJ, GŠ VJ, Kabinet NGŠ, Kolegijum načelnika Generalštaba Vojske Jugoslavije održan 11. 10. 2000, neautorizovan i nelektorisan magnetofonski snimak diskusija. VT-SP, Primerak br. 1.

${ }^{56}$ Isto, 19.

${ }^{57}$ Pored standardnog referisanja načelnika sektora i uprava, uočava se da načelnik Uprave bezbednosti general-potpukovnik Đaković predlaže „,da nas načelnik Resora DB Marković informiše o statusu njegove jedinice JSO u smislu da li je ili nije pod njegovom kontrolom“. Pomoćnik NGŠ za personalna pitanja general-potpukovnik Stamenko Nikolić izvestio je da je ,prikupio podatke o starešinama koje su stavljene na Vojnodisciplinski sud po pitanju stranačkog delovanja u ranijem periodu“. SRJ, GŠ VJ, Kabinet NGŠ, str. pov. br. 12-5, 15. 10. 2000. 
nivo borbene gotovosti i nismo dozvolili nikome da nas upotrebi van ustavnih i zakonskih okvira.

Da smo ostali dosledni u već proklamovanim načelima da poštujemo želju naroda i da se nećemo mešati u političku borbu.

Da poštujemo legitimne organe vlasti, a posebno predsednika SRJ dr Vojislava Koštunicu od momenta njegovog izbora i do sada izvršavamo njegove zahteve i naređenja.

Da nas ne interesuje rad političkih stranaka a susret sa pojedinim rukovodiocima istih realizuju se samo uz odobrenje predsednika SRJ Vojislava Koštunice“.

Načelnik Generalštaba je inicijativu dojučerašnjeg vrhovnog komandanta ocenio kao ,način pokušaja diskreditacije vojnog vrha“. Ukazao je da ,prethodni predsednik Slobodan Milošević mora da shvati da više ne može da ima uticaj na VJ kao saveznu instituciju“"i da će u kontaktu sa predsednikom Srbije Milutinovićem ,zahtevati da se više ne zahtevaju takvi kontakti“.

Kolegijum NGŠ je jednodušno podržao Pavkovićev stav. „Svi prisutni članovi Kolegijuma su u potpunosti saglasni sa odlukama NGŠ VJ i da su ga do sada podržavali u ovim teškim danima i da smatraju da je samo ovakav način ispravan i da treba da ostanemo jedinstveni kao GŠ VJ i VJ u celini. Svi su saglasni da je ovaj zahtev neopravdan i da ima za cilj da kompromituje Kolegijum NGŠ VJ i da treba predsedniku Milutinoviću preneti i da nas ostave da radimo u duhu ustavnih i zakonskih okvira“. ${ }^{58}$

Generalštab se tako jednoglasno svrstao uz novog predsednika SR Jugoslavije Koštunicu. Vernost vojnog vrha preusmerena je na nov politički centar moći, sve uz pozivanje na ustavne i zakonske okvire. Samo devet dana ranije, koristeći isto pozivanje na zakonske okvire, vojska je bila spremna za intervenciju protiv naroda i njegove izborne volje. Slično je bilo i sa rukovodiocima Resora državne bezbednosti.

General Pavković i najveći deo vojnog vrha su tako preživeli revolucionarnu političku promenu i ostali na svojim dužnostima. Štaviše, načelnik Generalštaba je u narednom periodu dobio daleko više samostalnosti u rukovođenju Vojskom i mogao je da se oslobodi nepoželjnih generala, a sebi privuče one koji su mu bili odani. Još gore, već naredne 2001. godine vojni vrh će, prvo diskretno a kasnije i otvoreno, početi da podržava predsednika Koštunicu u narastajućem političkom sukobu sa premijerom Republike Srbije Zoranom Đinđićem.

\section{REFERENCE}

- Bujošević Dragan, i Ivan Radovanović. 5. oktobar, Dvadeset četiri sata prevrata. Beograd: Medija centar, 2001.

- Dimitrijević, Bojan. Zoran Đinđić, Biografija. Beograd: Zavod za udžbenike, 2007.

- Jovanović, Čedomir. Moj sukob sa prošlošću. Beograd: Dan Graf, 2005.

${ }^{58}$ SRJ, GŠ VJ, Kabinet NGŠ str. pov. br. 12-5, 15. 10. 2000. 
BOJAN DIMITRIJEVIĆ, PhD, Principal Research Fellow

Institute for Contemporary History

Belgrade, Republic of Serbia

bojands1@gmail.com

\section{THE YUGOSLAV ARMY IN THE TURMOIL OF THE $5^{\text {TH }}$ OCTOBER 2000}

\section{Summary}

The article provides activities of the Yugoslav Army (Vojska Jugoslavije, VJ) and especially its General Staff in the period prior to and after the federal Yugoslav election held on $24^{\text {th }}$ September 2000. The majority of initial activities were linked to the political situation in Montenegro. The article reveals the preparation of the VJ "top brass" to deploy the forces against the protesters during the mass post-election rallies in Belgrade and all over Serbia. Those protests led to Slobodan Milošević's fall from political power and from his position as president of the Federal Republic of Yugoslavia. The newly elected FRY president became Vojislav Koštunica, leader of the Democratic Party of Serbia, who soon became accepted as the supreme commander of the Yugoslav Army's General Staff as the key military institution in the state. In the beginning it looked like the Army would take part against the protesters using standard repertoire of armored, engineer, and special forces. A preserved document testifies that preparations for intervention had been done, but that the huge opposition movement, masses of people on the streets, and the general disappointment with Milošević's twelve-year rule prevented the army from taking any action in the streets. The calming down of the post-revolutionary events and the top military brass remaining unchanged was satisfactory to the General Staff. An article was written on the unrevealed Vojska Jugoslavije documents. In 2003, Federal Defense Minister Boris Tadić asked the General Staff to provide the relevant documents on the role of the VJ in events around and during 5th October. The other group of documents represents transcripts from the General Staff meetings held in September and October of 2000, which had been declassified by that time by Lt General Ponoš, chief of the General Staff.

KEYWORDS: Serbia, Montenegro, Election, 5th October 2000, Slobodan Milošević, Vojislav Koštunica, Nebojša Pavković, Yugoslav Army, General Staff 